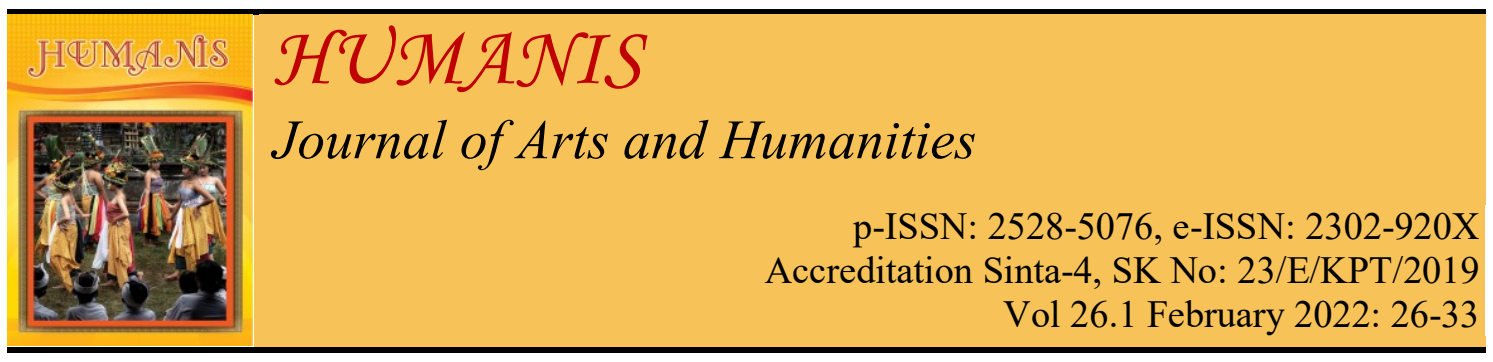

\title{
The Lexical Ambiguity in News Headlines of the Jakarta Post
}

\section{Ni Komang Desey Trisna Dewi S., I Made Suastra, I Komang Sumaryana Putra \\ Udayana University, Denpasar, Bali \\ Correspondence Email: deseytrisna@gmail.com , madesuastra@yahoo.co.id, komangsumaryana@,gmail.com}

\begin{tabular}{|c|c|}
\hline Article Info & Abstract \\
\hline $\begin{array}{l}\text { Submitted: } 17^{\text {th }} \text { December } 2021 \\
\text { Revised: } 19^{\text {th }} \text { January } 2022 \\
\text { Accepted: } 29^{\text {th }} \text { January } 2022 \\
\text { Keywords: } \\
\text { lexical ambiguity, homonymy, } \\
\text { polysemy, The Jakarta Post } \\
\text { Corresponding Author: } \\
\text { Ni Komang Desey Trisna Dewi } \\
\text { S. } \\
\text { email: deseytrisna@gmail.com } \\
\text { DoI: } \\
\text { https://doi.org/10.24843/JH.20 } \\
\text { 22.v26.i01.p04 }\end{array}$ & $\begin{array}{l}\text { The title of this study is "Lexical Ambiguity in News Headlines } \\
\text { of The Jakarta Post". This study deals with lexical ambiguity } \\
\text { and its factors. This study aims to identify the lexical ambiguity } \\
\text { and analyze the factors of lexical ambiguity. The data was taken } \\
\text { from The Jakarta Post's articles that were published throughout } \\
2019-2021 \text {. The documentation method and the note-taking } \\
\text { technique were used in collecting the data. The data was } \\
\text { analyzed by using the theory of lexical ambiguity proposed by } \\
\text { Ullmann (1967). The results of the study showed that there are } \\
\text { four words found as lexical ambiguity and two factors of lexical } \\
\text { ambiguity, namely polysemy and homonymy. The words 'flood' } \\
\text { and 'ghosting' are classified as homonymy, and the words } \\
\text { 'promise' and 'curfew' are classified as polysemy. }\end{array}$ \\
\hline
\end{tabular}

\section{INTRODUCTION}

Language is like an idea, emotion, and desire, which can produce symbols. According to Verderber (1999), language is the main body of words; it is the system they use in communication is shared by people from the same community or nation, in the same geographic area, the same culture or the same cultural tradition.

Language is an oral or written communication system used by humans to interact with others. In the use of language in communication, sometimes one person (speaker) can easily explain the meaning of a word or sentence. However, another person (listener) does not necessarily understand the word the speaker wants to say. This phenomenon is explained in the semantic discussion.
Semantics is the study of word and its relationship with its meaning. Griffiths (2006) states that semantics is a study of context-independent knowledge that language users have about the meaning of words and sentences. Meanwhile, according to Kreidler (1998), Semantics is an attempt to explain the speaker's knowledge of a language that allows the speaker to convey feelings, facts, products of imagination to others and understand what they are telling him or her.

Ambiguity is a language phenomenon that often occurs in daily communication. Leech (1981) stated that ambiguity is an expression when more than one interpretation can be apply to it and it can be considered ambiguous. This also emphasizes that ambiguity 
influenced by given context. It can be concluded that ambiguity gives room for alternative reactions to the same piece of language and happens when a word, phrase or sentence has more than one interpretation.

As an integral part of newspaper articles, news headlines are the focus of the news. The use of ambiguity in news headlines produces a humorous effect, arouses readers' curiosity and attracts their attention. However, some words, sentences or phrases in the news have two or more different meanings, which are generally called lexical ambiguities.

There are some articles related to this study. Anggur (2019) analyzed lexical ambiguity, grammatical ambiguity also what factors that influence the skills of writing from experience story text of IV grade students of The Champion Denpasar-Bali. The results showed that there are two types of ambiguity, lexical ambiguity also grammatical ambiguity. Polysemy and homonymy are part of lexical ambiguity, while there are four parts of grammatical ambiguity which including grammatical ambiguity caused by grammatical word formation events, grammatical vocabulary because of context in the sentence or lack of grammatical context, grammatical ambiguity in similar phrases and ambiguity caused by the grammatical structure is inaccurate. The factors that influence the writing skills are the use of a foreign language in daily conversation, the internal problem like a family environment, the intelligence related to students ability to absorb the materials, also interests are related to emotional responses, encouragement and motives. The study is relevant to this study because it discusses lexical ambiguity.

Charina (2017) analyzed the lexical ambiguity in which one word can be interpreted and have more than one interpretation and the structural ambiguity (syntactic) caused by the structure of the sentence. The result showed there are 25 cases of ambiguity in total. The result was divided into 12 sentences lexically ambiguous, and 13 sentences were syntactically ambiguous. Meanwhile, Dharmayanti (2017) have had analyzed the lexical ambiguity in the slogans of Unilever products. The study showed that in the first section, 10 slogans contained lexical ambiguity categorized as conceptual meaning, and 3 slogans categorized as connotative meaning. In the second section, there are 7 brand slogans that are polysemy as lexical factors, and 6 brand slogans are homonymy. The study is relevant to this study because it discusses lexical ambiguity. These two studies are relevant to this study because they discuss lexical ambiguity, as well as lexical factors, namely polysemy and homonymy.

Another article related to this study is from Ermika, et al. (2021) has analyzed ambiguity, including the lexical and grammatical in English Textbook for tenth-grade students. From this analysis of 21 reading texts, there are 27 sentences with ambiguity. There are three kind of lexical ambiguity which are polysemy, homonym (20.68\%), and antonym. The grammatical ambiguity consisted of coordinate structure (2.59\%), active or passive meaning, negation scope, gerund + object or participle modifying a noun, prepositional phrase (PP) as modifier or sentence adjunct, and a head of inner modifier and outer modifier. The study is relevant to this study because it discusses lexical ambiguity.

Faina, et al. (2021) analyzed the most dominant homonym of the lexical ambiguity used in the Coco movie script by Lee Unkrich and Adrian Molina. It just focused on the homonym used by Miguel as the main character in this movie. The result of the study showed there were 987 conversations of Coco movie script both in homophone and 
homograph. From 987 conversations of Coco movie script, it can be said that 226 conversations used the homophone words, consisted of 70 homophone words, and it occurred 645 times. Then, 70 conversations used the homograph words. It consisted of 29 homograph words, and it occurred in 06 times. So, it can be concluded that the most dominant homonym form of lexical ambiguity in Coco movie script was homophone which consisted of 70 words, and it occurred 645 times. In other articles, Kapadia \& Jufrizal (2013) analyzed the semantic ambiguity, including lexical and structural ambiguity in The Jakarta Post edition November and December 2012. The result of the study showed there are 113 ambiguities, including 60 lexical ambiguity $(53.10 \%)$ and 53 structural ambiguity $(46.90 \%)$. These two studies are relevant to this study because they also discuss about lexical ambiguity. The study by Kapadia Jufrizal take data from articles in The Jakarta Post, which are the same as the data sources in this study, but in different articles.

In an article related to this discussion, Pawestri \& Wongwattana (2018) analyzed the ambiguity found of Indonesian daily jokes in 'dagelan' which is an famous instagram account. The result of the study showed that jokes are formed with conversation and sentences consisting of independent also dependent clauses, even from the smaller phonetic form such as words and phrases. There are 10 types of ambiguity in this study, such as lexical ambiguity based jokes around $38 \%$ of the total, followed by phonological ambiguity based jokes at $19 \%$, and lexicalization of larger unit based jokes at $11 \%$, pragmatic ambiguity based jokes at $13 \%$, textual cohesion based jokes at $8 \%$, syntactic ambiguity based jokes at 5\%, orthographic jokes at $2 \%$, multiple ambiguity jokes at $2 \%$, type of modality jokes and deictic reference jokes at $1 \%$. The study is relevant to this study because it also discusses about lexical ambiguity.

Prasetyawan, et al. (2017) analyzed the ambiguity, including lexical ambiguity, referential ambiguity and syntactic ambiguity from 20 online recipes at bonappetit website editions from January until May 2017. The finding of the study showed that there are 34 total of ambiguity, including 9 lexical ambiguity $(26.47 \%) ; 2$ referential ambiguity (5.88\%); and 23 syntactic ambiguity (67.64\%). The syntactic ambiguity is the most dominant ambiguity in this study. In other articles, Purba, et al. (2020) analyzed the lexical and structural ambiguity in the opinion of The Jakarta Post from ten texts of opinion about Covid-19. The result of the analysis showed 26 lexical ambiguity and 16 structural ambiguities, including words, sentences, and phrases. These two studies are relevant to this study because they discuss about lexical ambiguity.

Puspitasari (2019) analyzed the lexical and structural ambiguity taken from nineteen Jakarta Post daily newspaper editions from November 14 to November 25, 2017. The result showed 20 ambiguous words from 8 cases of lexical ambiguities caused by polysemy and 12 cases of structural ambiguities caused by equivocal phrasing. Meanwhile, Rahman \& Nurjannah (2017) have had analyzed the ambiguity in the local wisdom. The result of this analysis is that the word classes found as ambiguities words are Nouns 46.6\%, Adjectives $33.33 \%$, Verbs $6.66 \%$, and Adverb $6.66 \%$. The study by Puspitasari relevant to this study because she discusses about lexical ambiguity and used articles from The Jakarta Post. The study by Rahman and Nurjannah are relevant to this study because it discusses about ambiguities.

The other article related to this discussion, Ramadhani (2015) analyzed to find the ambiguous words that have 
many lexical meanings from the headline of The Jakarta Post newspaper. The study showed the result of analysis from 9 headlines. There are 10 ambiguous words categorized as polysemy. Romadlani (2021) analyzed the manipulation of semantic meanings especially dealing with lexical semantics in humor creation strategy from Mind Your Language situation comedy. The result showed that the lexical-semantic is divided into five kinds: homonymy, homophone, hyponymy, and synonymy. These two studies are relevant to this study because they discuss about lexical ambiguity. The study by Ramadhani takes data from articles in The Jakarta Post, which are the same as the data sources in this study.

On the other hand, Sastraparamitha \& Martarini (2020) analyzed the ambiguity in five advertisements. The results of the analysis indicate that from four advertisements, one is caused by homonymy (plate 4: Advertisement of Facebook); two of the others are caused by puns and homonymy (plate $1 \& 2$ : Advertisements of Big Cola and McDonald); and the last is caused by metaphor (plate 3: Advertisement of Toyota PRIUS). The last article is from Yastanti \& Setiawati (2018), they have had analyzed the ambiguity in the soundtrack lyrics of the Moana movie. The result showed that in "We Know the Way" lyric, there are 26 ambiguity consist of 8 structural ambiguity and 18 lexical ambiguity; and there are 45 ambiguity, consist of 10 structural ambiguity and 35 lexical ambiguity in "I'm Moana" lyric. These two studies are relevant to this study because they also discuss about lexical ambiguity.

Based on the background given above, the problems that are discussed in this study are: (1) What is the lexical ambiguity found in the News Headlines of The Jakarta Post? (2) What lexical factors can lead to lexical ambiguity?

\section{METHOD AND THEORY}

The data in this study was taken from Jakarta Post that was published throughout 2019-2021, which includes all the ambiguous words, phrases, and sentences. The collected data was underlined and analyzed based on the theory of lexical ambiguity by Ullmann (1967). Lexical ambiguity is the presence of two or more possible meanings for a single word. It is the possibility of multiple interpretations of spoken or written language, without some additional information.

\section{RESULT AND DISCUSSIONS}

The analysis is focused on identifying the lexical ambiguity and analyzed the factors of lexical ambiguity. The theory was proposed by Ullmann (1967). There are two causal factors of lexical ambiguity, those are polysemy and homonymy. Polysemy is a fundamental feature of human speech, which can arise in a multiplicity of ways. The same word may have two or more different meaning. Homonymy is far less common and far less complex than polysemy, though its effects can be just as serious and even more dramatic.

\section{1/HO/SEP/25/19}

"Students throng in front of House, more flood into Jakarta as protests continue"

The headlines above considered as lexical ambiguity by the word flood. This word is classified as a homonymy. This word has lexical ambiguous meaning because it caused the reader to interpret its literal meaning which does not fit the meaning of the word in context. The word flood has several meanings by Oxford dictionary.

Flood (noun):

A large amount of water covering an area that is usually dry 
A very large number of things or people that appear at the same time

Based on the definitions of the word flood above the headlines might be interpreted into:

First interpretation:

"Students throng in front of House, more amount of water covering into Jakarta as protests continue."

Second interpretation:

"Students throng in front of House, more people appear at the same time into Jakarta as protests continue."

Between two interpretations above, the second interpretation fitted better with the news as it also showed on first paragraph below to have better understanding:

"Thousands of university students from across Indonesia have once again taken to the streets in a continuation of a series of protests against..." From the bold sentences, the writer intended to deliver that flood is a large amount of people which in this news are university students.

The causal factors of this lexical ambiguity word flood is homonyms because the pronounciation and spelling are identical but the meanings of this word completely different or unrelated.

\section{2/HO/MAR/24/21}

"Ghosting: Is the phenomenon of shutting people out acceptable?"

The headlines above is considered as lexical ambiguity by the word ghosting. The word ghosting comes from the basic word ghost added to suffix -ing. This word is classified as a homonymy. This word has lexical ambiguous meaning because it caused the reader to interpret its literal meaning which does not fit the meaning of the word in context. The word ghosting has several meanings by Oxford dictionary. As in oxford dictionary the word 'ghosting' has several meanings as below:

Ghosting (noun)
The appearance of a pale second image next to an image on a television screen, computer screen, etc.

The practice of ending a personal relationship with somebody by suddenly stopping all communication without explanation.

Based on the definitions of the word ghosting above the headlines might be interpreted into:

First Interpretation:

The appearance of a pale second image: Is the phenomenon of shutting people out acceptable?

Second Interpretation:

Ending a personal relationship with somebody by suddenly stopping all communication without explanation: Is the phenomenon of shutting people out acceptable?

Between two interpretations above, the second interpretation fitted better with the news as it also showed on first paragraph below to have better understanding:

"The term refers to the act of "disappearing" from someone's life, ceasing all contact with that person without any explanation and typically ignoring any contact attempts.." This paragraph could explain enough the meaning of word 'ghosting'.

The causal factors of this lexical ambiguity word ghosting is homonyms because the pronounciation and spelling are identical but the meanings of this word completely different or unrelated.

\section{3/PO/DEC/30/20}

"Regeneron says its COVID-19 antibody therapy showed promise in patients."

The headlines above is considered as lexical ambiguity by the word promise. This word is classified as a polysemy. This word has lexical ambiguous meaning because it caused the reader to interpret its literal meaning which does not fit the meaning of the word in 
context. The word promise has several meanings by Oxford dictionary below:

Promise (noun)

A sign, or a reason for hope that something may happen, especially something good

Promise (verb)

To tell somebody that you will definitely do or not do something, or that something will definitely happen

Based on the definitions of the word promise above the headlines might be interpreted into:

First Interpretation"

Regeneron says its COVID-19 antibody therapy showed something will definitely happen in patients.

Second Interpretation:

Regeneron says its COVID-19 antibody therapy showed a sign of something in patients.

Between two interpretations above, the first interpretation fitted better with the news as it also showed on first and fifth paragraph below to have better understanding:

"...its experimental antibody cocktail for use in some hospitalized COVID-19 patients show the therapy was sufficiently effective to warrant continuing the trial". In the last sentence of this paragraph tells that 'therapy was suffieciently effective', then the terapy produces a good result. As mentioned in the fifth paragraph, "Seronegative patients treated with the antibody cocktail had a lower risk of death or needing mechanical ventilation...". This proves that the word promise means 'something will definitely happen', not only 'a sign of someting'.

The causal factors of this lexical ambiguity word promise is polysemy because the pronounciation and spelling are the same. This word has different meaning but related senses. According to the one of the sources of the causal factors polysemy, namely shifts in application: the noun promise change into the verb meaning, with the same pronounciation and spelling..

\section{4/PO/JAN/03/21}

"Lockdowns, curfews, alcohol bans as nations fight resurgent virus."

The headlines above is considered as lexical ambiguity by the word curfew. This word is classified as a polysemy. This word has lexical ambiguous meaning because it caused the reader to interpret its literal meaning which does not fit the meaning of the word in context. The word curfew has several meanings by Oxford dictionary below:

Curfew (noun)

A law that says that people must not go outside after a particular time at night until the morning; the time after which nobody must go outside

A time when children must be home in the evening

Based on the definitions of the word curfew above the headlines might be interpreted into:

First Interpretation:

Lockdowns, the law of people must stay at home in particular time, alcohol bans as nations fight resurgent virus.

Second Interpretation:

Lockdowns, a time when children must be home in the evening, alcohol bans as nations fight resurgent virus.

Between two interpretations above, the first interpretation fitted better with the news as it also showed on nineteenth and twentieth paragraph below to have better understanding:

"The French government, facing the threat of a new wave of Covid-19 infections, lengthened an overnight curfew by two hours in parts of the country to help combat the virus.

"The curfew will start at $6 \mathrm{pm}$, rather than $8 \mathrm{pm}$ in parts of France, mainly in the country's east. Paris has, for now, been spared the additional restriction." 
On this two paragraph, the journalist did mention 'overnight curfew by two hours...to help combat the virus' and 'the curfew will start at 6 pm...', it means the word curfew more accurately refers to 'the law of people must stay at home in particular time' rather than to 'a time when children must be home'.

The causal factors of this lexical ambiguity word curfew is polysemy because the pronounciation and spelling are the same. This word has different meaning but related senses. According to the one of the sources of the causal factors polysemy, namely specialization in a social milieu: for a parenting, the word curfew will naturally means 'a time when children must be home in the evening'; for an urgency during pandemic it will means 'the law of people must stay at home in particular time'.

\section{CONCLUSION}

There are four words from four headline news articles that are categorized as lexical ambiguity. Homonymy and polysemy are two kinds of lexical ambiguity. The lexical factors of the word categorized as homonymy has the same spelling and pronunciation but the meaning can be different or completely different, such as the words 'flood' and 'ghosting'. The lexical factors of the word categorized as polysemy had different meanings but related senses such as the words 'curfew' and 'promise'.

\section{REFERENCES}

Anggur, B. (2019). Ambiguity in Writing Story Text of Experience of Grade IV Students of the Champion School Denpasar-Bali. RETORIKA: Jurnal Ilmu Bahasa, 5(1), 68-71

Charina, I. N. (2017). Lexical and Syntactic Ambiguity in Humor. IJHS 1 (1), 120-131
Dharmayanti, I G. A. D. (2017). Lexical Ambiguity in English Advertisement Slogans of Unilever Products. Humanis 19 (1), 93-101

Ermika, Sinambel, E., \& Pasaribu, A. N. (2021). Lexical \& Grammatical Ambiguities in English Textbook for Tenth Grade Students. International Journal of Educational Research \& Social Sciences 2 (3), 494-502

Faina, R., Rositasari, T., \& Elfarissyah, A. (2021). An Analysis of Lexical Ambiguity used in Coco Movie Script. English Community 5 (1), 19-26

Griffiths, P. (2006). An Introduction to English Semantics and Pragmatics. Edinburgh: Edinburgh University.

Kapadia, D., Jufrizal. (2013). Types of Semantic Ambiguity Found in the Editorials of Jakarta Post Daily Newspaper. English Language and Literature Online Journal 2 (1), 6776

Kreidler, C. W. (1998). Introducing English Semantic. London: Routledge.

Leech, G. (1974). Semantics. Great Britain: Hazell Watson \& Viney Ltd.

Pawestri, N., \& Wongwattana, U. (2018). Ambiguity in Indonesia Jokes on the Instagram "Dagelan". J. Phs: Conf. Ser, 1028 (012174)

Prasetyawan, K. E., Myartawan, I. P. N. W., \& Suprianti, G. A. P. (2017). An Analysis of Ambiguity in Online Recipes. JPBI Undiksha 5 (2)

Purba, D. K., Silalahi, D. E., Herman, \& Sihombing, P. S. R. (2020). An 
Analysis of Lexical and Structural Ambiguity in The Jakarta Post Newspaper. Actual Social Science Review 1 (1), 25-37

Puspitasari, J. (2019). Lexical and Structural Ambiguity found in Articles in the Jakarta Post Daily Newspaper. Humanis 23 (1), 19-24

Rahman, S., \& Nurjannah, N. (2017). Ambiguity Found in the Text Containing Local Wisdom. Perspective 5 (1), 59-71

Ramadhani, N. (2015). Lexical Ambiguity in the Headlines of The Jakarta Post Newspaper. Vivid: Journal of Language and Literature 4 (1)

Romadlani, M. M. I. (2021). A Manipulation of Semantic Meanings as a Humor Construction Strategy. Language Circle 15 (2), 293-304

Sastraparamitha, N. N. A. J., Martarini, N. M. L. (2020). Ambiguity of Meaning in English Advertisements. Litera 6 (1), 24-28

Yastanti, U., \& Setiawati, A. D. (2018). Ambiguity in Soundtrack Songs Lyric of Moana Movie. Wanastra, $10(2), 1-14$

Ullmann, S. (1967). Semantic: An Introduction to the Science of Meaning. Oxford: Basil Blackwell $\&$ Mott Ltd

Verdeber. (1999). Communicate!. New York: Wadsworth Publishing Company 